Published in final edited form as:

Cancer Epidemiol Biomarkers Prev. 2012 January ; 21(1): 191-201. doi:

10.1158/1055-9965.EPI-11-0670.

\title{
Lead, calcium uptake, and related genetic variants in association with renal cell carcinoma risk in a cohort of male Finnish smokers
}

\author{
Emily B. Southard ${ }^{1}$, Alanna Roff ${ }^{1}$, Tracey Fortugno ${ }^{1}$, John P. Richie Jr. ${ }^{1}$, Matthew Kaag ${ }^{2}$, \\ Vernon M. Chinchilli ${ }^{1}$, Jarmo Virtamo ${ }^{3}$, Demetrius Albanes ${ }^{4}$, Stephanie Weinstein ${ }^{4}$, and \\ Robin Taylor Wilson ${ }^{1}$
}

${ }^{1}$ Pennsylvania State University, College of Medicine, Department of Public Health Sciences, Hershey, PA, USA ${ }^{2}$ Pennsylvania State University, College of Medicine, Department of Surgery, Division of Urology, Hershey, PA, USA ${ }^{3}$ National Institute for Health and Welfare, Helsinki, Finland ${ }^{4}$ National Cancer Institute, Division of Cancer Epidemiology and Genetics, Bethesda, MD, USA

\begin{abstract}
Background-Lead $(\mathrm{Pb})$ is classified as a probable human carcinogen. However, its role in renal cell cancer (RCC) has not been established. Calcium and vitamin D may off-set toxicity in vivo.

Methods-In this nested case-control study, whole blood lead $(\mathrm{Pb})$, total serum calcium, and serum 25-hydroxyvitamin $\mathrm{D}$ were measured in blood drawn prior to diagnosis among male smokers participating in the Alpha-Tocopherol, Beta-Carotene Cancer Prevention Study. Single nucleotide polymorphisms (SNPs) in five genes (CALB1, TRPV5, TRPV6, VDR, and ALAD) related to lead toxicity or calcium transport were genotyped. Logistic and linear regression were used to determine RCC risk and time to diagnosis (respectively), adjusting for other risk factors.
\end{abstract}

Results-Among 154 newly diagnosed cases and 308 matched controls, RCC was associated with higher whole blood lead (OR=2.0, 95\% CI:1.0,3.9; quartile $\left.4(\mathrm{Q} 4) \mathrm{v} . \mathrm{Q} 1, \mathrm{P}_{\text {trend }}=0.022\right)$ and CALB1 rs1800645 $\left(\mathrm{P}_{\text {trend }}=0.025\right.$, minor ' $\mathrm{T}$ ' allele frequency $\left.=0.34\right)$. Higher total serum calcium $\left(\mathrm{P}_{\text {trend }}=<0.001\right)$ was associated with reduced RCC risk. Total serum calcium and 25-

hydroxyvitamin D levels did not alter the association observed with lead. Time from enrollment to RCC diagnosis was positively associated with serum calcium $\left(\mathrm{P}_{\text {trend }}=0.002\right)$ and 25-

hydroxyvitamin $\mathrm{D}\left(\mathrm{P}_{\text {trend }}=0.054\right)$ among cases.

Conclusions-Higher blood lead concentrations, below the $10 \mathrm{ug} / \mathrm{dL}$ level of concern, were associated with RCC, independent from serum calcium and $C A L B 1$ promoter polymorphism.

Impact-Increased risk of RCC is associated with lower serum calcium and higher whole blood lead in smokers. The clinical prognostic value of serum calcium and vitamin D in RCC should be further investigated.

\section{Keywords}

calcium; lead; vitamin D; renal cell carcinoma; polymorphism; CALB1

Corresponding author: Robin Taylor Wilson, $\mathrm{PhD}$, Associate Professor, Epidemiology Division, Department of Public Health Sciences, Penn State College of Medicine, Penn State Cancer Institute, 500 University Drive, Mail Code CH69, Hershey, PA 17033-0855, Phone: 717-531-7178 Fax: 717-531-5779, rwilson@ @su.edu. 


\section{Introduction}

Renal cell carcinoma (RCC), which accounts for $>80 \%$ of kidney cancers, has been increasing in incidence for the past several decades as high as 3 to $6 \%$ annually, depending on age, racial/ethnic group, and country (1-3). Known risk factors for renal cell carcinoma are similar to those for cardiovascular disease, including hypertension, diabetes, obesity, and tobacco smoking (4) - although, approximately half of all cases remain unexplained by currently known risk factors (5).

The International Agency for Cancer Research has classified inorganic lead compounds as a probable human carcinogen (Group 2A) and organic lead compounds are not classifiable as to their carcinogenicity (Group 3) (6). Exposure to lead compounds have gained more interest due to the exposure to the general population through air, contaminated soils, diet, and drinking water $(7,8)$. In animals, $\mathrm{Pb}$ primarily results in kidney tumors, with renal tumors being induced at low doses which do not cause nephrotoxicity (9). In humans, inorganic lead exposure is associated with a significant increase in risk of mortality from cancer and cancers of the stomach, lung, kidney and bladder $(10,11)$.

Animal studies have identified an inverse relationship between the uptake and toxicity of lead $(\mathrm{Pb})$ and calcium levels in the diet $(12,13)$. Vitamin $\mathrm{D}$ is a key regulator of calcium uptake in the gut and feeding studies in animals report increased lead concentrations in kidney and bone tissues among animals fed higher concentrations of vitamin D (14). Consistent with the hypothesis that calcium levels reduce lead uptake, multiple human studies have identified an inverse correlation between low bone mineral density and whole blood lead concentration $(15,16)$. Similarly, in vitro studies of kidney cells have found that $\mathrm{Pb}$ interferes with intracellular calcium mobilization, suggesting that lead exposure itself may suppress calcium uptake from the diet $(17,18)$. Animal trials suggest that uptake and adverse effects of lead may be enhanced among individuals with low calcium intake, and that lead levels, in turn, may influence circulating vitamin D levels (12). Importantly, genetic polymorphisms in genes related to calcium uptake may consequently influence uptake of lead. Such genes include those which encode for calcium channels (e.g., transient receptor potential cation channel, subfamily $\mathrm{V}$, member 5 ( TRPV 5 or transient receptor potential cation channel, subfamily $\mathrm{V}$, member 6 (TRPVG)), intracellular calcium chaperones (calbindin $128 \mathrm{kDa},(C A L B 1)$ ), and the vitamin $\mathrm{D}$ receptor $(V D R)$, known to regulate the expression of TRPV5, TRPV6, and $C A L B 1$. In addition, genetic variability in the Delta-aminolevulinic acid dehydratase $(A L A D)$ gene has been associated with differential toxicity to lead.(19-21)

Therefore, this study examines the risk of renal cell cancer in relation to concentrations of whole blood lead, dietary intake of calcium and vitamin D, total serum calcium, serum 25hydroxyvitamin $\mathrm{D}$, and genes related to calcium transport and lead toxicity. We investigate the possibility that 1) calcium and vitamin D may synergistically influence the risk of renal cell cancer associated with whole blood lead concentration and 2) calcium and vitamin D have an independent association with renal cell cancer and may act as confounders in the association between renal cell cancer and whole blood lead concentration.

\section{Materials and Methods}

\section{Cohort Participants and Matching Criteria}

We conducted a nested case-control study within the Alpha-Tocopherol, Beta-Carotene (ATBC) Cancer Prevention Study. ATBC enrolled nearly 30,000 male smokers aged 50-69 years in southwestern Finland from 1985-1988. As previously described, the ATBC study is a randomized, double-blind, placebo-controlled primary cancer prevention trial designed to 
determine the efficacy of daily supplementation with alpha-tocopherol, beta-carotene, or both in preventing lung cancer or other cancers (22). Participants were excluded from the ATBC study cohort if they smoked $<5$ cigarettes per day, had a prior history of cancer (other than non-melanoma skin cancer or carcinoma in situ), severe angina upon exertion, chronic renal insufficiency, liver cirrhosis, alcoholism, anticoagulant use, vitamin E supplementation (>20 mg/day), vitamin A supplementation (>20,000 IU/day), beta-carotene supplementation ( $>6 \mathrm{mg} /$ day), or other medical conditions that would prevent them from completing the six year trial. The Finnish Cancer Registry allows for patient diagnosis tracking long-term with nearly $100 \%$ ascertainment (23).

At baseline all participants were measured for height, weight, and blood pressure, and completed a questionnaire containing information on dietary intake, supplement use, medical history, physical activity, and smoking history. As described previously, dietary intake was obtained by a validated 12-month food frequency questionnaire consisting of modified diet history including both portion size and frequency of consumption (24). Cumulative lifetime smoking exposure was estimated in pack-years, with one pack-year equal to 20 cigarettes smoked per day for one year.

Our study utilized a nested case-control study of the ATBC cohort including 154 RCC cases and 308 controls. Cases newly diagnosed with RCC at least 5 years following enrollment into the ATBC study and at least 2 months after the whole blood draw were identified by linkage to the Finnish Cancer Registry and histologically confirmed as renal cell cancer (International Classification of Diseases, version 9, code 189.0) by linkage to the Finnish Cancer Registry. The medical records of the cases diagnosed through April 1999 were reviewed by one study physician to confirm the diagnosis of RCC whereas cases diagnosed after April 1999 were based solely on the Finnish Cancer Registry data (23). The first group of controls $(n=154)$ were matched on age at randomization ( \pm 7 years), whole blood draw date ( \pm 20 days within the same season), pack-years of smoking (matched on either above or below the median of the ATBC cohort of 35 pack-years), ATBC treatment group, and time to follow-up (i.e., controls having at least as much follow-up time as matched cases). The second group of ATBC controls $(\mathrm{n}=154)$ had been previously chosen for the Vitamin D Pooling Project (VDPP) and were matched on age at randomization ( \pm 1 year), whole blood draw date ( \pm 30 days within the same season), and assuring that the control is alive and cancer free at case diagnosis date (25).

\section{Whole Blood Lead, Serum Calcium, and Serum Vitamin D Measurements}

A 12-hour fasting serum sample was collected at baseline in 1985-1988 and whole blood was collected near or at the final trial visit between August 1992 and March 1993 in a Venoject tube with EDTA as an anti-coagulant. For all cases included in the study, blood and serum were drawn at least two months prior to cancer diagnosis. Whole blood lead concentrations were determined by inductively coupled plasma mass spectrometry at the Wisconsin State Laboratory of Hygiene. Study samples were run in duplicate and quality control samples and sample duplicate concentrations used for the study had to agree within $\pm 0.4 \mu \mathrm{g} / \mathrm{L}$ or $10 \%$. The ICP-MS assay measures total whole blood lead, including both organic and inorganic compounds.

The concentration of 25-hydroxyvitamin $\mathrm{D}$ (which includes both $25(\mathrm{OH}) \mathrm{D}_{2}$ and $25(\mathrm{OH}) \mathrm{D}_{3}$ ) was measured by direct, competitive chemiluminescence immunoassay at Heartland Assays, Inc. (Ames, Iowa), as described previously (25), on cases and VDPP controls. Sample batches included matched case-control sets and four to six blinded quality control (QC) specimens from our study and from two concentrations of standard reference material provided by the National Institute of Standards and Technology (NIST). Inter- and intrabatch coefficients of variation were $12.3 \%$ and $10.5 \%$, respectively, for the ATBC study 
QC samples. Total serum calcium was measured by colorimetric assay (BioVision, Mountain View, CA) at the Penn State University Core Endocrine Lab. This utilizes the chromogenic complex $(\lambda=575 \mathrm{~nm})$ formed between calcium ions and 0 -cresolphthalein in the physiological range of calcium concentration $0.4-100 \mathrm{mg} / \mathrm{dL}(0.1-25 \mathrm{mM})$. The average value between the two runs was used in the analysis. This assay spans the physiological range of calcium concentration $8.6-10.0 \mathrm{mg} / \mathrm{dL}(2.15-2.50 \mathrm{mM}), \mathrm{CV} \%=3.5 \%$.

\section{Genotyping, Gene Sequencing and Transfac Analysis}

TaqMan SNP genotyping assays (Applied Biosystems, Carlsbad CA) were purchased for four nonsynonymous coding region polymorphisms in genes with an established or functional role in calcium absorption/reabsorption, and lead $(\mathrm{Pb})$ toxicity: TRPV5, rs4252499 (Ala563Thr); TRPV6, rs4987682 (Met681Thr); VDR, rs2228570 (Met1Thr); and ALAD, rs1800435 (Lys59Asn). In addition, custom TaqMan SNP genotyping assays were designed for two polymorphisms in the CALB1 promoter (rs1800645 and rs16902897 at positions -366 and -490 relative to the transcription start site, respectively). Quantitative Real-Time PCR and allelic discrimination were conducted at the Genome Sciences Core Facility at the Penn State College of Medicine. Genotypes were successfully determined for $>99 \%$ of the samples with a reliability rate of $100 \%$ when a random $10 \%$ sample was again genotyped in a separate experiment.

DNA sequencing was conducted at the $C A L B 1$ promoter region in a random sample of 21 cases and controls in order to possibly identify any new polymorphisms. A 789-bp region of the proximal $C A L B 1$ promoter was PCR-amplified from genomic DNA using Phusion DNA polymerase (New England Biolabs) with the following primers: $5^{\prime}$ CTTATGAACCTGGTCAGATCCTTC-3' (forward) and 5' CTCAGCGTTCCTCCAGAGTTC-3' (reverse). The PCR products were gel-isolated using the QIAquick Gel Extraction Kit (QIAGEN), run on agarose gels to verify DNA recovery, and sequenced by automated cycle sequencing. Polymorphisms were identified by BLAST alignment with the wild-type sequence for human chromosome 8 (GenBank accession number NC_000008.10) and visual inspection of printed chromatograms. Resulting sequence variants were compared to data from NCBI (build 36, dbSNP b126). Experimentally-proven transcription factor binding sites near were identified within the human $C A L B 1$ promoter on chromosome 8 using BKL TRANSFAC Suite $(26,27)$.

\section{Statistical analysis}

All statistical analysis was performed using SAS version 9.2 (Sas Institute Inc., Cary NC). The statistical significance of mean differences of blood levels of calcium and lead between cases and controls were determined by the t-test statistic. Quantitative variables were divided into quartiles based on the distribution in both the cases and controls. The number of years from enrollment to cancer diagnosis was calculated as the number of days from enrollment to diagnosis divided by 365.25. Differences in categorical variables were tested by the Chi Squared test, and in the event of a cell size less than five, Fisher's exact test was used. For SNPs, the Chi Square Hardy Weinberg Equilibrium test was used to determine the observed to expected genotype frequency distributions among controls. The CochranArmitage $\mathrm{p}$-value was used to test for the $\mathrm{p}$-value of the trend by genotype.

Both conditional and unconditional logistic regression models were conducted and for simplicity the results of the conditional regression are presented in all tables. Adjusted conditional logistic regression models were calculated using Proc PHREG in SAS, adjusting for factors known to be associated with RCC, including age at randomization, systolic blood pressure, pack-years of smoking, BMI, alcohol intake, and other significant factors identified in this study. The selection of confounders was determined based on the existing 
literature which has identified age, smoking, body mass index, hypertension and alcohol use as consistently associated with RCC $(4,28,29)$. Subsequently, in the final multivariate model, we included only the known risk factors (listed above) and those statistically significant variables which were under investigation in our study (i.e., vitamin $\mathrm{D}$, calcium and lead). Due to the possibility that the differential matching criteria could have influenced our results, we investigated the final model using both sets of controls separately.

Two-way interactions were tested by multiplying the continuous value of each parameter together and testing the beta statistic for the interactive variable with the main effect terms in the adjusted conditional logistic regression model. Tests for trend were conducted by regressing the quartile value, adjusting for other factors in the model. The HosmerLemeshow goodness of fit test was conducted using unconditional multivariable logistic regression, with a p-value of $₫ 0.15$ indicating significant lack of fit (30). All statistical tests of significance ( $\mathrm{p} \unlhd$ (0.05) were two-tailed.

Due to the possibility for reverse causation (i.e., that the biomarker of interest may be influenced by sub-clinical cancer development itself), we investigated the association between number of years from enrollment to cancer diagnosis in association with total serum calcium, whole blood lead, serum 25-hydroxyvitamin D and genotype, adjusting for age at randomization, pack-years of smoking, body mass index and systolic blood pressure.

\section{Results}

The mean follow-up time was $12.1 \pm 4.1$ years (mean \pm standard deviation) for cases and $18.1 \pm 3.1$ years for controls (data not shown). Increased risk of RCC was associated with higher body mass index (BMI, $\left.P_{\text {trend }}=0.022\right)$, systolic blood pressure $\left(P_{\text {trend }}=0.014\right)$, and serum calcium concentration $\left(\mathrm{P}_{\text {trend }}<0.001\right)$, (Table 1). Higher blood lead concentration was significantly associated with RCC risk in the third quartile $(\mathrm{OR}=1.7,95 \% \mathrm{CI}: 1.0,3.1)$, although the overall crude trend was not statistically significant $\left(\mathrm{P}_{\text {trend }}=0.060\right)$. There were no differences between cases and controls in dietary calcium intake, dietary vitamin D intake, or employment "ever" in the following high risk occupations: mining, colliery (coal mining), quarrying, stonemasonry, stonecutting, foundry work, asbestos quarrying, asbestos fabric manufacture, asbestos concrete manufacture, asbestos insulating, lead refining, nickel refining, copper smelting, steel production/ refining, oil refining, gas manufacture, chromium paint manufacture, and arsenic production (Table 1). There was also no difference in supplemental vitamin $\mathrm{D}\left(\mathrm{P}_{\text {trend }}=0.651\right)$ or calcium $\left(\mathrm{P}_{\text {trend }}=0.233\right.$, data not shown).

The CALB1 promoter "TT" genotype at the -366 position (rs1800645, CALB1-366) was significantly more prevalent among cases $(\mathrm{OR}=2.4,95 \%$ CI: 1.1, 5.0, "TT" versus "AA", $\left.\mathrm{P}_{\text {trend }}=0.008\right)$, Table 2 . This polymorphism is located within 112 base pairs of a putative vitamin D response element (VDRE), Figure 1 (31). DNA sequencing of the CALB1 promoter revealed no novel polymorphisms. A binding site for RE1-Silencing Transcriptional factor (REST) was located at position -611 to -593 (TRANSFAC accession \# FR000215353), and an Sp1 transcription factor binding site was located at position -120 to -108 (TRANSFAC accession \#FR000121598), which do not overlap with either of the CALB1 SNPs $(27,32)$.

In adjusted models, higher concentration of total serum calcium was associated with decreased RCC risk $\left(\mathrm{P}_{\text {trend }}<0.001\right)$, adjusted for age at randomization, pack-years of smoking, systolic blood pressure, BMI, alcohol intake, whole blood lead, and CALB1p-366 genotype (Table 3). Conversely, a higher concentration of whole blood lead $\left(\mathrm{P}_{\text {trend }}=0.022\right)$ and the CALB1-p366 "TT" genotype $\left(\mathrm{P}_{\text {trend }}=0.057\right)$ was associated with increased risk 
(Table 3). There was not a significant interaction between whole blood lead and total serum calcium on risk of RCC ( $\mathrm{P}_{\text {interaction }}=0.538$, data not shown). Results for whole blood lead were similar but the magnitude of association was more pronounced using only controls from the VDPP (Q4 v. Q1: OR=3.1, 95\% CI: 1.1, 8.4), although the trend was not statistically significant ( $\mathrm{p}$-trend $=0.300$ ). Similarly, total serum calcium remained statistically significant using only VDPP controls (Q4 v. Q1: OR=0.4, 95\% CI: 0.2, 1.0, p-trend = $0.005)$.

$C A L B 1$-p366 remained associated with RCC risk among individuals with the CALB1-p366 "TT" genotype (OR $=2.8,95 \%$ CI: 1.0, 7.4), although the trend by the number of "T" allele copies was of borderline significance $(\mathrm{p}=0.057)$. There was not a significant interaction between $C A L B 1$-p366 genotype and serum calcium $\left(\mathrm{P}_{\text {interaction }}=0.180\right)$, although risk ratios were significantly elevated among individuals with low serum calcium and the CALB1-p366 "TT" genotype ("combined variable model", Table 3). There was not a significant interaction between whole blood lead and the $C A L B 1$-p366 polymorphism $\left(\mathrm{P}_{\text {interaction }}=0.175\right.$, data not shown $)$.

Among cases alone, time to RCC diagnosis after study enrollment was associated with and baseline serum calcium $\left(\mathrm{P}_{\text {trend }}=0.002\right)$, and serum 25-hydroxyvitamin $\mathrm{D}\left(\mathrm{P}_{\text {trend }}=0.054\right)$, adjusting for other RCC risk factors (age at randomization, pack-years of smoking, BMI and systolic blood pressure, Table 4).

\section{Discussion}

\section{Summary}

This study observed a 2-fold increased risk of RCC with concentrations of whole blood lead at or above $3.31 \mu \mathrm{g} / \mathrm{dL}$, and dose-dependent reduced risks among those with higher total serum calcium levels and/or the "A" allele of the CALB1p-366 SNP located in the promoter of the $C A L B 1$ gene.

\section{Lead and Renal Cell Cancer}

Harmful effects of lead on the renal system have been described since antiquity and increasingly documented with industrialization $(33,34)$. It is currently hypothesized that renal carcinogenesis due to lead uptake in the kidney is mediated by oxidative damage to the proximal renal tubule, where more than $95 \%$ of renal cell cancers develop $(35,36)$. Over three-fold higher concentrations of lead in renal cortex tissues of kidney cancer patients compared with cadaver controls have been reported, although the results of these studies are limited by their small number of subjects (37). In a representative sample of US residents, the NHANES III Mortality Study documented a higher rate of death from all causes as well as death from cardiovascular disease and cancer among participants ages 40 and older with blood lead levels above $5 \mathrm{ug} / \mathrm{dL}$ (cancer mortality HR=1.44, 95\% CI: $1.12-1.86$ for $5-9 \mathrm{ug} /$ $\mathrm{dL} ; \mathrm{HR}=1.69,95 \% \mathrm{CI}: 1.14,2.52$ for $\geq 10 \mathrm{ug} / \mathrm{dL}$ versus $<5 \mathrm{ug} / \mathrm{dL}, \mathrm{P}_{\text {trend }}<0.01 ; 8.5$ years median follow-up time) (38). In the same cohort, Jemal et al. (2002) report a 3.2-fold higher risk of kidney cancer mortality after an average of 13 years of follow-up among men with blood levels $\geq 13.0 \mathrm{ug} / \mathrm{dL}$ at baseline, although not statistically significant (39). In our study, risks for incident RCC were significantly elevated by 2-fold for men with blood lead levels above $3.31 \mathrm{ug} / \mathrm{dL}$, a blood level which is lower than previous studies reporting significant associations $(39,40)$.

We observed no attenuation of risk according to either dietary or blood biomarkers of calcium or vitamin D, as we might have expected given the results of earlier animal studies. However, animal studies have focused on higher doses of lead and in fact not all animal studies report that calcium intake prevents dietary uptake of lead (41). We also observed no 
association with the delta-aminolevulinic acid dehydratase gene $(A L A D)$ gene polymorphism, previously associated with lead toxicity $(21,42)$-- possibly due to the small number of cases with the at risk genotype.

There were no significant differences in occupational history or smoking history between cases and controls in our study that would sufficiently explain the association we observed. In Finland, lead was banned in indoor paint in 1929 and, as in other countries, the use of tetraethyl lead in gasoline reached its peak in the 1970s, and once banned led to a significant drop in childhood blood lead concentrations, although recurring seasonal exposure due to resuspension of contaminated urban soils has been suggested $(7,43)$. Thus, the predominant source of lead exposure for the general population in Finland (and ATBC participants) near the time this study was tetraethyl leaded gasoline $(34,44)$. In a 1975 study, healthy men living in Helsinki had an average blood lead concentration of $11.4 \mu \mathrm{g} / \mathrm{dl}(34,44)$. Because whole blood lead remains the best biomarker of lead using routine blood draw techniques (45), blood lead in this study was measured in the only whole blood sample taken in the ATBC study which was drawn toward the study end (1992-1993). Therefore, it is possible that the levels we measured in blood drawn in 1992-1993 are lower than had we been able to obtain a whole blood sample at the time of study enrollment. Season of blood draw was a matching factor for cases and controls and therefore is not likely a confounding factor.

Overall, there are few well-powered epidemiologic studies to fully assess an association between blood lead and RCC or blood lead and cancer risk (11). While animal studies have identified increased blood lead levels among animals fed low calcium diets (46), the results of our study suggest that blood lead levels and serum calcium levels may be independently associated with RCC risk.

\section{Calcium Intake and Total Serum Calcium}

We observed a significant dose-response reduction in the risk of renal cell cancer with higher serum calcium concentration. In an ad hoc analysis, factors significantly associated with total serum calcium were BMI and dietary intake of vitamin D, milk, alpha linolenic acid, and oleic acid, as identified through stepwise regression (data not shown). Adjustment for these factors did not alter the association observed with total serum calcium. Low dietary calcium and serum calcium concentration have both been associated with several cancers including RCC (47-50), although not consistently (51-53). We did not account for total serum albumin and therefore do not know bound versus free calcium levels. However, the major causes for hypoalbuminemia, such as chronic kidney or liver disease, were exclusion criteria for this study. The fact that we did not also observe an association with dietary calcium might be related to a higher average calcium intake in Finland relative to other countries $(24,54)$. The food frequency correlation between reported and actual calcium intake is 0.70 (24) so inaccurate patient recall could account for the fact that we found an association between serum levels but not for dietary intake. Finally, the association between total serum calcium and RCC remained statistically significant even after adjustment for other dietary factors which were associated with total serum calcium.

\section{Vitamin D and Its Regulatory Proteins}

Our study is consistent with other studies reporting no association between serum 25hydroxyvitamin D and incident RCC (25). The majority of glomerular-filtered calcium in the kidney $(\sim 65 \%)$ is reabsorbed passively in the proximal renal tubule. In the distal tubule, final regulation of $\mathrm{Ca}^{2+}$ excretion occurs where $1,25\left(\mathrm{OH}_{2} \mathrm{D}_{3}\right.$ stimulates uptake of calcium via increased expression of TRPV5 on the apical membrane, as well as cytosolic calbindin D28K (encoded by the CALB1 gene), and $\mathrm{Na}^{+} / \mathrm{Ca}^{2+}$ exchanger (NCX1) on the basolateral membrane (55). PTHR1 over-expression has been identified in RCC (56). However, we 
observed no significant associations with polymorphisms in TRPV5 (rs4252499 leading to in an amino acid change (Ala563Thr) associated with differences in $\mathrm{Ca}^{2+}$ influx (57)), TRPV6 (rs4987682 leading to amino acid change Met681Thr associated with a gain of function haplotype $(58,59)$ ), or vitamin D receptor ( $V D R$ (rs2228570 leading to amino acid change M1T associated with increased transcriptional efficiency(60)).

\section{Calbindin}

CALB1, located on chromosome $8 \mathrm{q} 21$, is expressed primarily in the kidney and is involved in the regulation of the reabsorption of calcium in the distal tubule, acting as an intra-cellular calcium buffer and regulating apical calcium channel uptake by controlling the amount of free $\mathrm{Ca}^{2+}(61)$. Notably, its expression appears to be unaltered by changes in dietary calcium (62) Toxicologically, it may mediate cyclosporin A-induced calciuria and tubular calcification, and its function may be significantly altered in hypertensive disease (63), although elevated incidence of tumors have not been reported in $C A L B 1$ knock-out animals (62). It is possible that the promoter polymorphism (-366) we observed in association with RCC may influence the level of calbindin D28K expression in the kidney, although this is not known. Transfection experiments in several cell lines, including human embryonic kidney cells, suggest that increased calbindin D28K expression reduces the amount of cell death under pro-apoptotic conditions (64).

Although the interaction between $C A L B 1 \mathrm{p}-366$ and calcium was not statistically significant, the 6-fold odds ratio we observed with the "TT" genotype for individuals with below median serum calcium seems noteworthy. Lower serum calcium might influence conformational changes in Calbindin due to the number of bound calcium ions (65). Calbindin D28K binds four calcium ions in an ordered fashion within its EF hands 1, 3, 4, and 5; once all four ions are bound, a disulfide bond forms between cysteines 94 and 100, in-turn influencing surface hydrophobicity and altering its ability to interact with other proteins including those involved in apoptosis (e.g. procaspase-3) $(65,66)$. The possibility of interaction should be further investigated.

\section{Time to RCC Diagnosis}

Hypercalcemia has been associated with poor survival outcomes in localized (67) and metastatic RCC treated with targeted therapy, after adjustment for serum protein levels (68, 69). However, less is known regarding serum calcium and serum 25 -hydroxyvitamin $D$ as predictors of time to development of RCC when measured in apparently healthy individuals. One plausible explanation is that the time to development of RCC is influenced by calcium through systolic blood pressure. A recent systematic review of randomized trials identified significant evidence for the use of calcium supplementation in reducing systolic blood pressure in hypertension (54). However, our results may also indicate that reverse causation is possible-i.e., it is possible that the undetected development of RCC may influence serum calcium and vitamin D concentrations. Studies with multiple serum measurements over time in cases prior to cancer development will help to determine whether this might be the case or not.

\section{Strengths and Limitations}

The strengths of this study include a very low patient drop-out rate due to the Finnish patient tracking system. Dietary assessments were performed using a validated food frequency questionnaire prior to diagnosis which limits assessment bias (24). Diagnosis was confirmed by linkage to the Finnish Cancer Registry. The Finnish population is generally homogenous, which reduces the likelihood that the genetic association with the $C A L B 1 \mathrm{SNP}$ is due to stratification alone. 
With regard to the strengths of this study, it is possible that due to the sample size, there was not sufficient power to identify multiplicative interactions and associations with more rare genetic variants. Whole blood used for lead measurement was not taken at the time of enrollment into ATBC, but near the end of the study (a minimum of 2 months before RCC diagnosis), and since originally collected for other purposes, no special handling was undertaken to prevent lead contamination. Additionally, a single time point does not necessarily indicate long-term lifetime exposures to lead. The quantification of serum calcium did not include measurement of ionized calcium and/or serum albumin and therefore did not measure bound versus unbound calcium levels. Finally, our study was conducted in a cohort of smokers willing to participate in a dietary intervention trial and therefore the results may not be generalizable to other population groups.

\section{Conclusion}

This study suggests that high concentrations of whole blood lead, low concentrations of total serum calcium, and $C A L B 1$ genotypes may be risk factors for incident renal cell carcinoma among smokers. Further, total serum calcium and 25-hydroxyvitamin D among asymptomatic individuals may be positively associated with the time to RCC diagnosis, suggesting that these biomarkers may be subject to reverse causation-i.e. are pre-clinically influenced by development of the tumor itself. Further studies are warranted to identify early RCC biomarkers.

\section{Acknowledgments}

American Institute for Cancer Research, Grant No. 200810 awarded to RTW

Special thanks to Genome Sciences Core Facility at the Penn State College of Medicine, Dr. Willard Freeman, Director; Rusty Shields, IMS; Kirk Snyder, IMS; Noel Stanton, Wisconsin State Laboratory of Hygiene; and Dr. Laurence M. Demers, Director of the Penn State Hershey Core Endocrine Lab.

\section{References}

1. Mathew A, Devesa SS, Fraumeni JF Jr, Chow WH. Global increases in kidney cancer incidence, 1973-1992. 2002; 11:171-178.

2. Ward EM, Thun MJ, Hannan LM, Jemal A. Interpreting cancer trends. Ann N Y Acad Sci. 2006; 1076:29-53. [PubMed: 17119192]

3. Wilson RT, Richardson LC, Kelly JJ, Kaur J, Jim MA, Lanier AP. Cancers of the urinary tract among American Indians and Alaska Natives in the United States, 1999-2004. Cancer. 2008; 113:1213-1224. [PubMed: 18720377]

4. Moore LE, Wilson RT, Campleman SL. Lifestyle factors, exposures, genetic susceptibility and renal cell cancer risk: A Review Cancer Research. 2005; 23:240-255.

5. Brannon AR, Rathmell WK. Renal cell carcinoma: where will the state-of-the-art lead us? Curr Oncol Rep. 2010; 12:193-201. [PubMed: 20425079]

6. (IARC) IAfROC. , editor. Inorganic and Organic Lead Compounds. Lyon, France: IARC; 2006.

7. Mielke HW, Laidlaw MA, Gonzales CR. Estimation of leaded $(\mathrm{Pb})$ gasoline's continuing material and health impacts on 90 US urbanized areas. Environ Int. 2011; 37:248-257. [PubMed: 20825992]

8. Edwards M, Triantafyllidou S, Best D. Elevated blood lead in young children due to leadcontaminated drinking water: Washington, DC, 2001-2004. Environ Sci Technol. 2009; 43:16181623. [PubMed: 19350944]

9. Silbergeld EK, Waalkes M, Rice JM. Lead as a carcinogen: experimental evidence and mechanisms of action. Am J Ind Med. 2000; 38:316-323. [PubMed: 10940970]

10. Silbergeld EK. Facilitative mechanisms of lead as a carcinogen. Mutat Res. 2003; 533:121-133. [PubMed: 14643416] 
11. Fu H, Boffetta P. Cancer and occupational exposure to inorganic lead compounds: a meta-analysis of published data. Occup Environ Med. 1995; 52:73-81. [PubMed: 7757170]

12. Fullmer CS. Lead-calcium interactions: involvement of 1,25-dihydroxyvitamin D. Environ Res. 1997; 72:45-55. [PubMed: 9012371]

13. Dowd TL, Rosen JF, Gundberg CM, Gupta RK. The displacement of calcium from osteocalcin at submicromolar concentrations of free lead. Biochim Biophys Acta. 1994; 1226:131-137. [PubMed: 8204659]

14. Hart MH, Smith JL. Effect of vitamin D and low dietary calcium on lead uptake and retention in rats. J Nutr. 1981; 111:694-698. [PubMed: 6260915]

15. Campbell JR, Auinger P. The association between blood lead levels and osteoporosis among adults--results from the third national health and nutrition examination survey (NHANES III). Environ Health Perspect. 2007; 115:1018-1022. [PubMed: 17637916]

16. Khalil N, Cauley JA, Wilson JW, Talbott EO, Morrow L, Hochberg MC, et al. Relationship of blood lead levels to incident nonspine fractures and falls in older women: the study of osteoporotic fractures. J Bone Miner Res. 2008; 23:1417-1425. [PubMed: 18410230]

17. Olivi L, Cascio S, Wang S, Bressler J. Mobilization of intracellular calcium in kidney epithelial cells is inhibited by lead. Toxicology. 2002; 176:1-9. [PubMed: 12062925]

18. Pokorski PL, McCabe MJ Jr, Pounds JG. Lead inhibits meso-2,3-dimercaptosuccinic acid induced calcium transients in cultured rhesus monkey kidney cells. Toxicology. 1999; 134:19-26. [PubMed: 10413185]

19. Weaver VM, Lee BK, Todd AC, Ahn KD, Shi W, Jaar BG, et al. Effect modification by deltaaminolevulinic acid dehydratase, vitamin $\mathrm{D}$ receptor, and nitric oxide synthase gene polymorphisms on associations between patella lead and renal function in lead workers. Environ Res. 2006; 102:61-69. Epub 2006 Feb 17. [PubMed: 16487505]

20. Schwartz BS, Lee BK, Lee GS, Stewart WF, Simon D, Kelsey K, et al. Associations of blood lead, dimercaptosuccinic acid-chelatable lead, and tibia lead with polymorphisms in the vitamin D receptor and [delta]-aminolevulinic acid dehydratase genes. Environ Health Perspect. 2000; 108:949-954. [PubMed: 11049814]

21. Kelada SN, Shelton E, Kaufmann RB, Khoury MJ. Delta-aminolevulinic acid dehydratase genotype and lead toxicity: a HuGE review. Am J Epidemiol. 2001; 154:1-13. [PubMed: 11427399]

22. The alpha-tocopherol, beta-carotene lung cancer prevention study: design, methods, participant characteristics, and compliance. The ATBC Cancer Prevention Study Group. Ann Epidemiol. 1994; 4:1-10. [PubMed: 8205268]

23. Korhonen P, Malila N, Pukkala E, Teppo L, Albanes D, Virtamo J. The Finnish Cancer Registry as follow-up source of a large trial cohort--accuracy and delay. Acta Oncol. 2002; 41:381-388. [PubMed: 12234031]

24. Pietinen P, Hartman AM, Haapa E, Rasanen L, Haapakoski J, Palmgren J, et al. Reproducibility and validity of dietary assessment instruments. I. A self-administered food use questionnaire with a portion size picture booklet. Am J Epidemiol. 1988; 128:655-666. [PubMed: 2458036]

25. Gallicchio L, Moore LE, Stevens VL, Ahn J, Albanes D, Hartmuller V, et al. Circulating 25Hydroxyvitamin D and Risk of Kidney Cancer. American Journal of Epidemiology. 2010; 172:4757. [PubMed: 20562187]

26. BIOBASE. 2010. http://biobase-international.com/pages/index.php?id=transfac

27. Matys V, Kel-Margoulis OV, Fricke E, Liebich I, Land S, Barre-Dirrie A, et al. TRANSFAC and its module TRANSCompel: transcriptional gene regulation in eukaryotes. Nucleic Acids Res. 2006; 34:D108-D110. [PubMed: 16381825]

28. Chow, WH.; Devesa, SS.; Moore, LE. Epidemiology of Renal Cell Carcinoma. In: Vogelzang, NJ.; Scardino, PJ.; Shipley WU, FMJ.; D, WML., editors. Comprehensive Textbook of Genitourinary Oncology. 2nd ed.. Philadelphia: Lippincott Williams \& WIlkins; 2004. p. 110

29. Setiawan VW, Stram DO, Nomura AM, Kolonel LN, Henderson BE. Risk factors for renal cell cancer: the multiethnic cohort. Am J Epidemiol. 2007; 166:932-940. [PubMed: 17656615]

30. Hosmer DW, Hosmer T, Le Cessie S, Lemeshow S. A comparison of goodness-of-fit tests for the logistic regression model. Stat Med. 1997; 16:965-980. [PubMed: 9160492] 
31. Gill RK, Christakos S. Identification of sequence elements in mouse calbindin-D28k gene that confer 1,25-dihydroxyvitamin D3- and butyrate-inducible responses. Proc Natl Acad Sci U S A. 1993; 90:2984-2988. [PubMed: 8464915]

32. Valouev A, Johnson DS, Sundquist A, Medina C, Anton E, Batzoglou S, et al. Genome-wide analysis of transcription factor binding sites based on ChIP-Seq data. Nat Methods. 2008; 5:829_ 834. [PubMed: 19160518]

33. Oliver, T., editor. Lead poisoning, from the industrial, medical, and social points of view: lectures delivered at the Royal Institute of Public Health. Great Britain: P.B. Hoeber; 1914.

34. Hernberg S. Lead poisoning in a historical perspective. Am J Ind Med. 2000; 38:244-254. [PubMed: 10940962]

35. Wang Y, Jacobs EJ, McCullough ML, Rodriguez C, Thun MJ, Calle EE, et al. Comparing methods for accounting for seasonal variability in a biomarker when only a single sample is available: insights from simulations based on serum 25-hydroxyvitamin d. Am J Epidemiol. 2009; 170:8894. [PubMed: 19406919]

36. Conterato GM, Augusti PR, Somacal S, Einsfeld L, Sobieski R, Torres JR, et al. Effect of lead acetate on cytosolic thioredoxin reductase activity and oxidative stress parameters in rat kidneys. Basic Clin Pharmacol Toxicol. 2007; 101:96-100. [PubMed: 17651309]

37. Cerulli N, Campanella L, Grossi R, Politi L, Scandurra R, Soda G, et al. Determination of Cd, Cu, $\mathrm{Pb}$ and $\mathrm{Zn}$ in neoplastic kidneys and in renal tissue of fetuses, newborns and corpses. J Trace Elem Med Biol. 2006; 20:171-179. [PubMed: 16959594]

38. Schober SE, Mirel LB, Graubard BI, Brody DJ, Flegal KM. Blood lead levels and death from all causes, cardiovascular disease, and cancer: results from the NHANES III mortality study. Environ Health Perspect. 2006; 114:1538-1541. [PubMed: 17035139]

39. Jemal A, Graubard BI, Devesa SS, Flegal KM. The association of blood lead level and cancer mortality among whites in the United States. Environ Health Perspect. 2002; 110:325-329. [PubMed: 11940448]

40. Lustberg M, Silbergeld E. Blood lead levels and mortality. Arch Intern Med. 2002; 162:24432449. [PubMed: 12437403]

41. Bogden JD, Gertner SB, Kemp FW, McLeod R, Bruening KS, Chung HR. Dietary lead and calcium: effects on blood pressure and renal neoplasia in Wistar rats. J Nutr. 1991; 121:718-728. [PubMed: 2019881]

42. Weaver VM, Schwartz BS, Ahn KD, Stewart WF, Kelsey KT, Todd AC, et al. Associations of renal function with polymorphisms in the delta-aminolevulinic acid dehydratase, vitamin D receptor, and nitric oxide synthase genes in Korean lead workers. Environ Health Perspect. 2003; 111:1613-1619. [PubMed: 14527840]

43. Silbergeld EK. Preventing lead poisoning in children. Annu Rev Public Health. 1997; 18:187-210. [PubMed: 9143717]

44. Nordman CH, Hernberg S. Blood lead levels and erythrocyte delta-amino-levulinic acid dehydratase activity of selected population groups in Helsinki. Scand J Work Environ Health. 1975; 1:219-232. [PubMed: 1228901]

45. Barbosa F Jr, Tanus-Santos JE, Gerlach RF, Parsons PJ. A critical review of biomarkers used for monitoring human exposure to lead: advantages, limitations, and future needs. Environ Health Perspect. 2005; 113:1669-1674. [PubMed: 16330345]

46. Ahamed M, Siddiqui MK. Environmental lead toxicity and nutritional factors. Clin Nutr. 2007; 26:400-408. [PubMed: 17499891]

47. Peterlik M, Cross HS. Vitamin D and calcium deficits predispose for multiple chronic diseases. Eur J Clin Invest. 2005; 35:290-304. [PubMed: 15860041]

48. Wu K, Willett WC, Fuchs CS, Colditz GA, Giovannucci EL. Calcium Intake and Risk of Colon Cancer in Women and Men. J Natl Cancer Inst. 2002; 94:437-446. [PubMed: 11904316]

49. Prineas R, Folsom A, Zhang Z, Sellers T, Potter J. Nutrition and other risk factors for renal cell carcinoma in postmenopausal women. Epidemiology. 1997; 8:31-36. [PubMed: 9116091]

50. Hu J, Mao Y, White K. Diet and vitamin or mineral supplements and risk of renal cell carcinoma in Canada. Cancer Causes and Control. 2003; 14:705-714. [PubMed: 14674734] 
51. Chlebowski RT, Johnson KC, Kooperberg C, Pettinger M, Wactawski-Wende J, Rohan T, et al. Calcium plus vitamin D supplementation and the risk of breast cancer. J Natl Cancer Inst. 2008; 100:1581-1591. [PubMed: 19001601]

52. Wactawski-Wende J, Kotchen JM, Anderson GL, Assaf AR, Brunner RL, O'Sullivan MJ, et al. Calcium plus Vitamin D Supplementation and the Risk of Colorectal Cancer. N Engl J Med. 2006; 354:684-696. [PubMed: 16481636]

53. Mellemgaard A, McLaughlin J, Overvad K, Olsen J. Dietary risk factors for renal cell carcinoma in Denmark. European Journal of Cancer. 1996; 32A:673-682. [PubMed: 8695272]

54. Chung M, Balk EM, Brendel M, Ip S, Lau J, Lee J, et al. Vitamin D and calcium: a systematic review of health outcomes. Evid Rep Technol Assess (Full Rep). 2009:1-420. [PubMed: 20629479]

55. Boros S, Bindels RJ, Hoenderop JG. Active $\mathrm{Ca}(2+)$ reabsorption in the connecting tubule. Pflugers Arch. 2009; 458:99-109. [PubMed: 18989697]

56. Lupp A, Klenk C, Rocken C, Evert M, Mawrin C, Schulz S. Immunohistochemical identification of the PTHR1 parathyroid hormone receptor in normal and neoplastic human tissues. Eur $\mathbf{J}$ Endocrinol. 2010; 162:979-986. [PubMed: 20156969]

57. Na T, Zhang W, Jiang Y, Liang Y, Ma HP, Warnock DG, et al. The A563T variation of the renal epithelial calcium channel TRPV5 among African Americans enhances calcium influx. Am J Physiol Renal Physiol. 2009; 296:F1042-F1051. [PubMed: 19261737]

58. Hughes DA, Tang K, Strotmann R, Schoneberg T, Prenen J, Nilius B, et al. Parallel selection on TRPV6 in human populations. PLoS One. 2008; 3:e1686. [PubMed: 18301763]

59. Suzuki Y, Pasch A, Bonny O, Mohaupt MG, Hediger MA, Frey FJ. Gain-of-function haplotype in the epithelial calcium channel TRPV6 is a risk factor for renal calcium stone formation. Hum Mol Genet. 2008; 17:1613-1618. [PubMed: 18276610]

60. Jurutka PW, Remus LS, Whitfield GK, Thompson PD, Hsieh JC, Zitzer H, et al. The polymorphic $\mathrm{N}$ terminus in human vitamin $\mathrm{D}$ receptor isoforms influences transcriptional activity by modulating interaction with transcription factor IIB. Mol Endocrinol. 2000; 14:401-420. [PubMed: 10707958]

61. Hoenderop JG, Nilius B, Bindels RJ. Molecular mechanism of active Ca2+ reabsorption in the distal nephron. Annu Rev Physiol. 2002; 64:529-549. [PubMed: 11826278]

62. Sooy K, Kohut J, Christakos S. The role of calbindin and 1,25dihydroxyvitamin D3 in the kidney. Curr Opin Nephrol Hypertens. 2000; 9:341-347. [PubMed: 10926169]

63. Petrazzuolo O, Trepiccione F, Zacchia M, Capasso G. Hypertension and renal calcium transport. J Nephrol. 23(Suppl 16):S112-S117. [PubMed: 21170867]

64. Christakos S, Liu Y. Biological actions and mechanism of action of calbindin in the process of apoptosis. J Steroid Biochem Mol Biol. 2004:89-90. 401-404.

65. Hobbs CA, Deterding LJ, Perera L, Bobay BG, Thompson RJ, Darden TA, et al. Structural characterization of the conformational change in calbindin-D28k upon calcium binding using differential surface modification analyzed by mass spectrometry. Biochemistry. 2009; 48:86038614. [PubMed: 19658395]

66. Kojetin DJ, Venters RA, Kordys DR, Thompson RJ, Kumar R, Cavanagh J. Structure, binding interface and hydrophobic transitions of Ca2+-loaded calbindin-D(28K). Nat Struct Mol Biol. 2006; 13:641-647. [PubMed: 16799559]

67. Magera JS Jr, Leibovich BC, Lohse CM, Sengupta S, Cheville JC, Kwon ED, et al. Association of Abnormal Preoperative Laboratory Values with Survival After Radical Nephrectomy for Clinically Confined Clear Cell Renal Cell Carcinoma. Urology. 2008; 71:278-282. [PubMed: 18308103]

68. Patil S, Figlin RA, Hutson TE, Michaelson MD, Négrier S, Kim ST, et al. Prognostic factors for progression-free and overall survival with sunitinib targeted therapy and with cytokine as first-line therapy in patients with metastatic renal cell carcinoma. Annals of Oncology. 2011; 22:295-300. [PubMed: 20657034]

69. Choueiri TK, Garcia JA, Elson P, Khasawneh M, Usman S, Golshayan AR, et al. Clinical factors associated with outcome in patients with metastatic clear-cell renal cell carcinoma treated with 
vascular endothelial growth factor-targeted therapy. Cancer. 2007; 110:543-550. [PubMed: 17577222] 


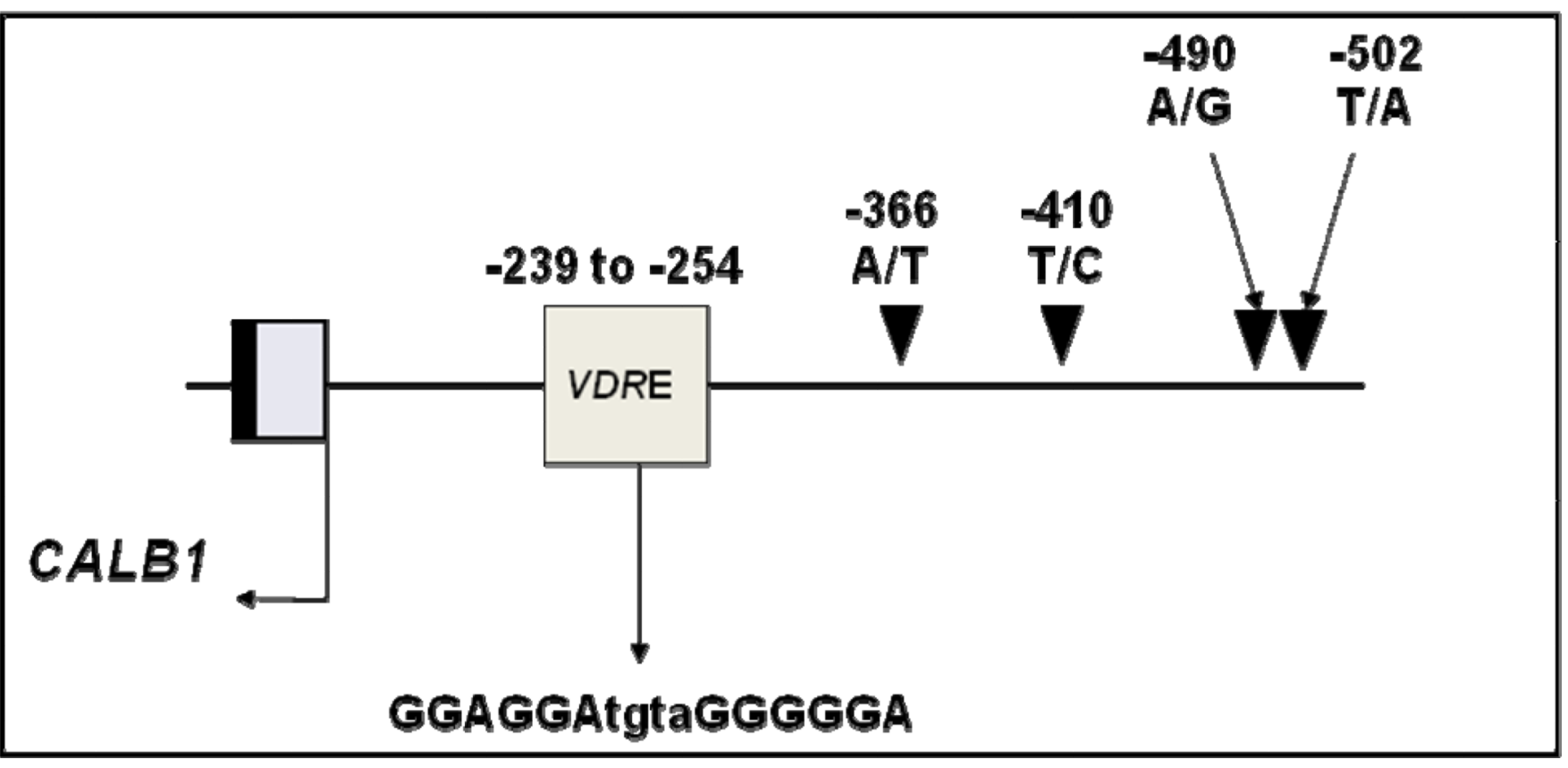

Figure 1.

Map of known single nucleotide polymorphisms in the $C A L B 1$ promoter. The -366 promoter variant found to be associated in this study is in close proximity to a putative vitamin D response element ( VDRE) based on the published murine VDRE. 
Table 1

Unadjusted Odds Ratios of Renal Cell Cancer, Alpha-Tocopherol, Beta-Carotene Cancer Prevention Study

\begin{tabular}{|c|c|c|c|c|c|c|c|c|}
\hline \multirow[b]{2}{*}{ Body Mass Index (kg/m²) } & \multicolumn{2}{|c|}{$\begin{array}{l}\text { No. and } \\
\text { Percent of } \\
\text { cases }\end{array}$} & \multicolumn{2}{|c|}{$\begin{array}{l}\text { No. and } \\
\text { Percent of } \\
\text { controls }^{a}\end{array}$} & \multirow[t]{2}{*}{$\begin{array}{l}\text { Quartile } \\
\text { Median }\end{array}$} & \multirow[t]{2}{*}{$\begin{array}{l}\text { Odds } \\
\text { Ratio }\end{array}$} & \multirow[t]{2}{*}{$\begin{array}{c}95 \% \\
\text { Confidence } \\
\text { Interval }\end{array}$} & \multirow[t]{2}{*}{$P_{\text {trend }}$} \\
\hline & $\mathrm{N}$ & $\%$ & $\mathrm{~N}$ & $\%$ & & & & \\
\hline 17.8 to 24.0 & 28 & 18 & 87 & 28 & 22.8 & Reference & & \\
\hline 24.1 to 26.2 & 38 & 25 & 77 & 25 & 25.2 & 1.5 & $0.9,28$ & \\
\hline 26.3 to 28.3 & 43 & 28 & 73 & 24 & 27.2 & 1.8 & $1.0,3.3$ & \\
\hline 28.4 to 40.7 & 45 & 29 & 71 & 23 & 30.5 & 1.9 & $1.1,3.2$ & 0.022 \\
\hline \multicolumn{9}{|c|}{ Systolic Blood Pressure (mmHg) } \\
\hline $100-129$ & $<5$ & 3 & 17 & 6 & N/A & Reference & & \\
\hline $130-139$ & 42 & 27 & 102 & 33 & N/A & 2.8 & $1.5,5$ & \\
\hline $140-153$ & 65 & 42 & 121 & 39 & N/A & 2.3 & $1.3,4.3$ & \\
\hline $154-226$ & 43 & 28 & 68 & 22 & N/A & 2.7 & $1.4,5.1$ & 0.014 \\
\hline \multicolumn{9}{|l|}{ Dietary Calcium (mg/d) } \\
\hline 206.4 to 1019.3 & 40 & 26 & 75 & 24 & 773.2 & Reference & & \\
\hline 1019.4 to 1313.4 & 34 & 22 & 82 & 27 & 1150.6 & 0.8 & $0.4,1.4$ & \\
\hline 1313.5 to 1668.7 & 43 & 28 & 72 & 23 & 1479.6 & 1.1 & $0.7,1.9$ & \\
\hline 1668.8 to 3854.2 & 37 & 24 & 79 & 26 & 1932.9 & 0.9 & $0.5,1.5$ & 0.756 \\
\hline \multicolumn{9}{|l|}{ Dietary Vitamin D (ug/d) } \\
\hline 0.7 to 3.4 & 77 & 50 & 39 & 13 & 2.6 & Reference & & \\
\hline 3.5 to 4.8 & 78 & 51 & 37 & 12 & 4.3 & 0.9 & $0.5,1.6$ & \\
\hline 4.9 to 7.1 & 82 & 53 & 33 & 11 & 6 & 0.8 & $0.5,1.4$ & \\
\hline 7.2 to 17.6 & 71 & 46 & 45 & 15 & 9.1 & 1.3 & $0.7,2.2$ & 0.507 \\
\hline \multicolumn{9}{|c|}{ Alcoholic Beverage Intake (g/d) } \\
\hline 0 to 23.3 & 45 & 29 & 70 & 23 & 0 & Reference & & \\
\hline 23.4 to 88.0 & 36 & 23 & 81 & 26 & 58.1 & 0.7 & $0.4,1.2$ & \\
\hline 88.1 to 214.2 & 42 & 27 & 68 & 22 & 133.1 & 1.0 & $0.6,1.6$ & \\
\hline 214.3 to 2009.0 & 31 & 20 & 90 & 29 & 425.6 & 0.5 & $0.3,0.9$ & 0.124 \\
\hline \multicolumn{9}{|c|}{ High Risk Occupational Group $b$} \\
\hline Yes & 25 & 16 & 54 & 18 & 1 & 0.9 & $0.6,1.5$ & \\
\hline No & 129 & 84 & 254 & 82 & 0 & Reference & & 0.360 \\
\hline \multicolumn{9}{|c|}{ Serum calcium concentration (mg/dL) } \\
\hline 6.8 to 9.4 & 46 & 30 & 69 & 22 & 9.2 & Reference & & \\
\hline 9.5 to 9.9 & 44 & 29 & 67 & 22 & 9.7 & 1.0 & $0.6,1.7$ & \\
\hline 10.0 to 10.2 & 29 & 19 & 53 & 17 & 10.1 & 0.8 & $0.5,1.5$ & \\
\hline 10.3 to 14.0 & 35 & 23 & 119 & 39 & 10.6 & 0.4 & $0.3,0.8$ & $<0.001$ \\
\hline \multicolumn{9}{|c|}{ Serum $25-\mathrm{OH}$ vitamin $\mathrm{D}(\mathrm{ng} / \mathrm{mL})^{\mathcal{c}}$} \\
\hline 0.2 to 8.5 & 34 & 23 & 36 & 27 & 6.1 & Reference & & \\
\hline 8.6 to 13.0 & 36 & 25 & 33 & 25 & 10.7 & 1.2 & $0.6,2.3$ & \\
\hline 13.1 to 18.6 & 40 & 28 & 30 & 23 & 16.2 & 1.4 & $0.7,2.8$ & \\
\hline 18.7 to 36.7 & 35 & 24 & 34 & 26 & 22.6 & 1.2 & $0.6,2.5$ & 0.475 \\
\hline
\end{tabular}




\begin{tabular}{lcccccccc}
\hline & $\begin{array}{c}\text { No. and } \\
\text { Percent of } \\
\text { cases }\end{array}$ & $\begin{array}{c}\text { No. and } \\
\text { Percent of } \\
\text { controls }^{\boldsymbol{a}}\end{array}$ & $\begin{array}{l}\text { Quartile } \\
\text { Median }\end{array}$ & $\begin{array}{c}\text { Odds } \\
\text { Ratio }\end{array}$ & $\begin{array}{c}\text { 95\% } \\
\text { Confidence } \\
\text { Interval }\end{array}$ & $\boldsymbol{P}_{\text {trend }}$ \\
\hline Blood lead concentration $(\mu \mathrm{g} / \mathrm{dL})$ & & & & & & & & \\
$\quad \begin{array}{l}27 \\
\text { to } 2.4\end{array}$ & 20 & 81 & 27 & 2.0 & Reference & & \\
2.5 to 3.2 & 31 & 23 & 81 & 27 & 2.9 & 1.1 & $0.6,2.1$ & \\
3.3 to 4.6 & 40 & 29 & 70 & 23 & 3.9 & 1.7 & $0.9,3.2$ & \\
4.7 to 15.2 & 38 & 28 & 72 & 24 & 5.8 & 1.7 & $0.9,3.1$ & 0.240 \\
\hline
\end{tabular}

${ }^{a}$ Cases and controls were matched on age at randomization, serum and whole blood draw dates, pack-years, ATBC treatment group, and follow-up time.

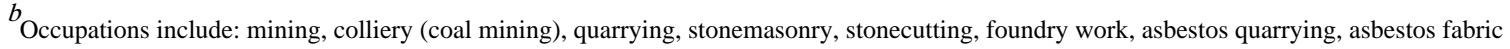
manufacture, asbestos concrete manufacture, asbestos insulating, lead refining, nickel refining, copper smelting, steel production/ refining, oil refining, gas manufacture, chromium paint manufacture, and arsenic production. P-trend based on the total number of high risk occupations.

$c^{c}$ Only one set of controls had vitamin D serum measurements. 


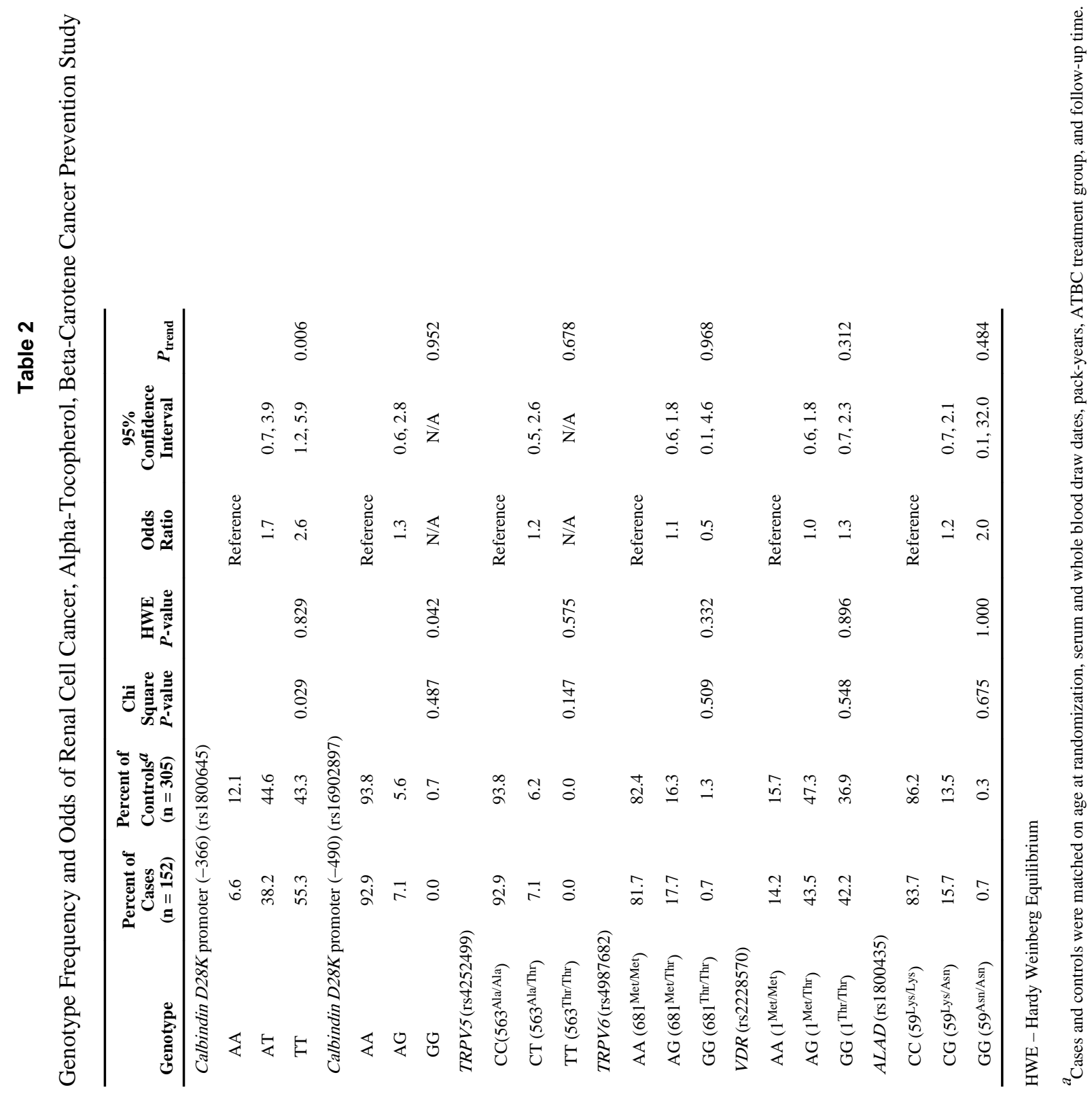




\section{Table 3}

Adjusted Odds of Incident Renal Cell Cancer, Alpha-Tocopherol, Beta-Carotene Cancer Prevention Study Cohort

\begin{tabular}{|c|c|c|c|}
\hline & $\begin{array}{c}\text { Adjusted Odds } \\
\text { Ratio }^{a}\end{array}$ & $\begin{array}{c}95 \% \\
\text { Confidence } \\
\text { Interval }\end{array}$ & $\boldsymbol{P}_{\text {trend }} \mathbf{P}_{\text {interaction }}$ \\
\hline \multicolumn{4}{|l|}{ Total serum calcium, mg/dL } \\
\hline$<9.50$ & Reference & & \\
\hline$\geq 9.50-10.00$ & 0.9 & $0.5,1.7$ & \\
\hline$\geq 10.00-10.30$ & 0.7 & $0.4,1.4$ & \\
\hline$\geq 10.30$ & 0.3 & $0.2,0.7$ & $<0.001$ \\
\hline \multicolumn{4}{|l|}{ Whole blood lead, $\mu \mathrm{g} / \mathrm{dL}$} \\
\hline$<2.50$ & Reference & & \\
\hline$\geq 2.50-3.31$ & 1.1 & $0.6,2.0$ & \\
\hline$\geq 3.31-4.66$ & 1.8 & $1.0,3.6$ & \\
\hline$\geq 4.66$ & 2.0 & $1.0,3.9$ & 0.022 \\
\hline \multicolumn{4}{|l|}{ Calbindin D28K promoter (-366) (rs1800645) } \\
\hline AA & Reference & & \\
\hline AT & 2.3 & $0.9,6.1$ & \\
\hline TT & 2.8 & $1.0,7.4$ & 0.057 \\
\hline Hosmer-Lemeshow Goodness of Fit P-value & & & 0.430 \\
\hline
\end{tabular}

\section{Combined Variable Model:}

High Total Serum Calcium ${ }^{b}$ and Calbindin D28K promoter (-366) (rs1800645)

$\begin{array}{lcc}\text { AA } & \text { Reference } & \\ \text { AT } & 2.3 & 0.5,11.4 \\ \text { TT } & 2.8 & 0.6,13.4\end{array}$

Low Total Serum Calcium and Calbindin D28K promoter (-366) (rs1800645)

$\begin{array}{lll}\text { AA } & 2.3 & 0.4,14.1 \\ \text { AT } & 4.6 & 0.9,23.1 \\ \text { TT } & 6.0 & 1.7,29.2\end{array}$

Interaction P-value

0.180

${ }^{a}$ All odds ratios adjusted for age at randomization, pack-years of smoking, systolic blood pressure, body mass index, alcohol intake, total serum calcium, serum lead $(\mathrm{Pb})$ and Calbindin D28K promoter (-366) (rs 1800645) genotype using conditional logistic regression. Cases and controls were matched on age at randomization, serum and whole blood draw dates, pack-years, ATBC treatment group, and follow-up time.

$b_{\text {In }}$

Interaction model high total serum calcium defined as above median $(\geq 10.00 \mathrm{mg} / \mathrm{dl})$. 


\section{Table 4}

Time from Study Enrollment to Renal Cell Cancer Diagnosis and Concentrations of Total Serum Calcium, Whole Blood Lead, Serum Vitamin D, and Calbindin Polymorphism. Alpha-Tocopherol, Beta-Carotene Cancer Prevention Study

\begin{tabular}{|c|c|c|c|c|}
\hline & $\begin{array}{l}\text { Mean Total } \\
\text { Serum Calcium } \\
(\mathrm{mg} / \mathrm{dL})\end{array}$ & $\begin{array}{l}\text { Mean Whole } \\
\text { Blood Lead } \\
(\mathrm{Pb})(\mathrm{ug} / \mathrm{dL})^{a}\end{array}$ & $\begin{array}{c}\text { Mean Serum 25- } \\
\text { Hydroxyvitamin D } \\
\text { (ng/ml) }\end{array}$ & $\begin{array}{l}\text { Calbindin D28K } \\
\text { "TT" Genotype } \\
\text { Frequency }(\%)\end{array}$ \\
\hline \multicolumn{5}{|c|}{ Total Years from Study Enrollment to Cancer Diagnosis } \\
\hline 5.0 to 8.9 & 9.5 & 4.1 & 12.9 & 55.3 \\
\hline 9.0 to 11.7 & 9.7 & 3.6 & 14.2 & 55.3 \\
\hline 11.8 to 15.1 & 9.8 & 3.7 & 14.7 & 59.5 \\
\hline 15.2 to 20.9 & 9.9 & 4.5 & 15.8 & 51.3 \\
\hline $\begin{array}{l}\text { Adjusted Beta } \\
\text { Coefficient } b\end{array}$ & 1.5 & 0.2 & 0.1 & -0.3 \\
\hline$P_{\text {trend }}$ & 0.002 & 0.269 & 0.054 & 0.641 \\
\hline
\end{tabular}

a Whole blood lead was drawn after study enrollment and at least two months prior to RCC diagnosis.

$b_{\text {Case }}$ value for genotype is for 0,1 or 2 copies of the calbindin D28K T allele. 